\title{
LOCAL AREA TRAFFIC MANAGEMENT PADA JALAN PERKOTAAN KAWASAN PENDIDIKAN DAN PEMUKIMAN (STUDI KASUS JALAN GAJAH MADA KOTA PADANG)
}

\author{
Endri $^{1}$, Yossyafra $^{2}$, dan Hendra Gunawan ${ }^{3}$
}

\begin{abstract}
ABSTRAK
Kota Padang sebagai kota besar dengan jumlah penduduk \pm 860.000 jiwa memiliki permasalahan transportasi seperti kemacetan lalu lintas di beberapa ruas jalan terutama pada jam-jam sibuk, yaitu pagi (jam masuk sekolah/kantor), dan sore (saat pulang). Ruas jalan Gajah Mada merupakan salah satu jalan penghubung antara sub-pusat kegiatan yaitu pasar satelit Alai dan pasar satelit Siteba. Pada ruas jalan ini juga terdapat beberapa institusi pendidikan, perkantoran dan komplek perumahan,seperti pada segmen antara simpang J1 Gajah Mada - Jl STKIP PGRI dan simpang Jl Gajah Mada - Jl Perumahan Tabiang Banda Gadang yang sering terjadi kemacetan lalu lintas pada jam sibuk pagi dan sore. Dari hasil observasi lapangan terhadap simpang Jl Gajah Mada - Jl STKIP PGRI dan simpang Jl Gajah Mada - Jl Perumahan Tabiang Banda Gadang didapatkan kapasitas simpang sebesar 2.739 smp/jam dan 2.738 smp/jam, Derajat kejenuhan (DS) 0.76 dan 0,76, dan Tundaan simpang (D) 12,74 detik dan 12, 42 de-tik,serta Indek Tingkat Pelayanan "D" dan “ D”. Untuk itu perlu adanya upaya pengaturan lalu lintas pada kawasan tersebut guna meningkatkan kinerja simpang dan ruas jalan yaitu dengan memisahkan arus lalu lintas keluar masuk dari dan ke jalan lokal. Dengan melakukan manajemen lalu lintas pada kawasan tersebut maka disimpang J1 Gajah Mada - J1 STKIP PGRI,terjadi peningkatan kapasitas simpang $40 \%$, mengurangi Tundaan simpang \pm 2 - 3 detik serta meningkatkan Indek Tingkat Pelayanan dari "D" menjadi "C". Sedangkan untuk simpang Jl Gajah Mada - Jl Perumahan Tabiang Banda Gadang terjadi peningkatan Kapasitas simpang $32 \%$, mengurangi Tundaan simpang \pm 2 - 3 detik dan meningkatkan Indek Tingkat Pelayanan dari "D” menjadi " $C$ ".
\end{abstract}

Kata kunci : local area traffic management,kinerja simpang, kinerja ruas jalan

\section{PENDAhUluan}

Fakta menunjukan bahwa dengan bertambahnya pengguna jalan terutama sekali pada waktu-waktu tertentu menuntut adanya peningkatan kualitas dan kuantitas suatu jalan. Untuk itu perlu adanya penelitian mengenai jalan yang ada untuk dievaluasi, dianalisa dan diantisipasi permasalahan lalu lintas khususnya di ruas jalan yang ada di kota Padang.Dengan adanya pengaturan lalu lintas dan fasilitas lalu lintas yang bermanfaat, terutama sekali untuk warga pada komplek perumahan/pemukiman karena bisa menghemat biaya dan mengurangi waktu perjalanan.

Pada kawasan pendidikan dan pemukiman yang berada di ruas jalan Gajah Mada kota Padangmerupakan salah satu jalan penghubung antara sub-pusat kegiatan yaitu pasar satelit Alai dan pasar satelit Siteba.Pada ruas jalan ini jugaterdapat beberapa institusi pendidikan, perkantoran dan komplek perumahan,seperti pada segmen antara simpang Jl Gajah Mada - Jl STKIP PGRI dan

\footnotetext{
${ }^{1}$ Mahasiswa Pascasarjana Jurusan Teknik Sipil Fakultas Teknik Universitas Andalas endrist170@gmail.com

${ }^{2}$ Staf Pengajar Jurusan Teknik Sipil Fakultas Teknik Universitas Andalas, yossyafra@ft.unand.ac.id

${ }^{3}$ Staf Pengajar Jurusan Teknik Sipil Fakultas Teknik Universitas Andalas hendra@ft.unand.ac.id
} 
simpang Jl Gajah Mada - Jl Perumahan Tabiang Banda Gadang yang sering terjadi kemacetan lalu lintas pada jam sibuk pagi dan sore. Berdasarkan pengamatan lapangan saat jam puncak pagi dan sore institusi pendidikan dan perkantoran tersebut merupakan penarik perjalanan yang cukup besar terutama sekali untuk moda transportasi kendaraan pribadi berupa kendaraan roda dua dan mobil pribadi.

Tujuan penelitian ini adalah untuk mengeva-luasi dan mengusulkan solusi penanganan kemacetan lalu lintas guna meningkatkan kinerja simpang dan ruas jalan pada ruas jalan Gajah Mada, pada segmen simpang Jl Gajah Mada - Jl STKIP PGRI dengan simpang Jl Gajah Mada - Jl Perumahan Tabiang Banda Gadangdengan konsep ma-najemen lalu lintas kawasan(Local Area Traffic Management) LATM.

\section{LANDASAN TEORI}

\subsection{Kapasitas}

Arus Lalu lintas berinteraksi dengan sistem jaringan transportasi.Jika arus lalu lintas meningkat pada ruas jalan tertentu, semakin tinggi waktu tempuh yang dibutuhkan.Arus maksimum yang dapat melewati suatu ruas jalan disebut kapasitas ruas jalan tersebut (Tamin, 2000).

Kapasitas ruas jalan perkotaan biasanya di-nyatakan dengan kendaraan atau dalam Sa-tuan Mobil Penumpang (smp) per jam.Hubungan antara arus dengan waktu tempuh atau kecepatan tidaklah linear. Pe-nambahan kendaraan tertentu pada saatarus rendah akan menyebabkan penambahan waktu tempuh yang kecil jika dibandingkan dengan penambahan kendaraan pada saat arus tinggi. Jika arus lalu lintas mendekati kapasitas, kemacetan mulai terjadi. Kema-cetan semakin meningkat apabila arus begitu besarnya sehingga kendaraan sangat ber-dekatan satu sama lain atau bergerak sangat lamban.Sedangkan menurut Direktur Jen-deral Bina Marga, 1997 "Manual Kapasitas Jalan Indonesia"(MKJI) Kapasitas jalan adalah jumlah lalu lintas kendaraan maksi-mum yang dapat ditampung pada ruas jalan selama kondisi tertentu (desain geometri, lingkungan, dan komposisi lalu lintas) yang dapat ditentukan dalam satuan massa pe-numpang untuk setiap satuan waktu (smp/jam)

\section{Kapasitas Simpang tak Bersinyal}

Untuk nilai kapasitas Simpang digunakan rumus :Direktur Jenderal Bina Marga, 1997 "Manual Kapasitas Jalan Indonesia"(MKJI)

$$
\mathrm{C}=\mathrm{C}_{\mathrm{O}} \times \mathrm{F}_{\mathrm{w}} \times \mathrm{F}_{\mathrm{M}} \times \mathrm{F}_{\mathrm{CS}} \times \mathrm{F}_{\mathrm{RSU}} \mathrm{F}_{\mathrm{LT}} \times \mathrm{F}_{\mathrm{RT}} \times \mathrm{F}_{\mathrm{MI}}(\mathrm{smp} / \mathrm{jam}) .
$$

Dimana :
C : Kapasitas (smp/jam)
$\mathrm{C}_{\mathrm{O}} \quad$ : Kapastas dasar untuk kondisi tertentu (smp/jam)
$\mathrm{F}_{\mathrm{W}} \quad$ : Faktor penyesuaian lebar pendekat
$\mathrm{F}_{\mathrm{M}} \quad$ : Faktor penyesuaian median jalan utama
$\mathrm{F}_{\mathrm{CS}} \quad$ : Faktor penyesuaian ukuran kota
$\mathrm{F}_{\mathrm{RSU}}$ : Faktor penyesuaian tipe lingkungan jalan, hambatan samping dan kendaraan tak bermotor
$\mathrm{F}_{\mathrm{LT}} \quad$ : Faktor penyesuaian belok kiri
$\mathrm{F}_{\mathrm{RT}} \quad$ : Faktor penyesuaian belok kanan
$\mathrm{F}_{\mathrm{MI}} \quad$ : Faktor penyesuaian arus jalan minor 


\section{Kapasitas Ruas Jalan}

Untuk nilai kapasitas Ruas Jalan digunakan rumus :Direktur Jenderal Bina Marga, 1997 "Manual Kapasitas Jalan Indonesia"(MKJI)

$$
\left.\mathrm{C}=\mathrm{C}_{\mathrm{O}} \mathrm{x} \text { Fcw } \times \text { FCsp } \times \text { FCsf } \times \text { FCcs(smp/jam }\right)
$$

Dimana :

$$
\begin{array}{lll}
\text { Fcw } & : \text { Faktor penyesuaian lebar jalur lalu lintas } \\
\text { FCsp } & : \text { Faktor penyesuaian pemisah arah. } \\
\text { FCsfFCcs } & : \text { Faktor penyesuaian hambatan samping. } \\
& : \text { Faktor penyesuaian ukuran kota. }
\end{array}
$$

\section{Derajat kejenuhan (Ds)}

Derajat kejenuhan (Ds) merupakan rasio arus terhadap kapasitas yang digunakan sehingga faktor utama dalam penentuan tingkat kinerja dan segmen jalan, nilai derajat kejenuhan juga menunjukkan apakah segmen jalan tersebut mempunyai masalah kapasitas atau tidak. Derajat kejenuhan pada jalan tertentu dihitung sebagai berikut :

$$
\mathrm{Ds}=\mathrm{Q} / \mathrm{C}
$$

Dimana :

Ds : Derajat kejenuhan (smp/jam)

Q : Kapasitas arus lalu lintas (smp/jam)

C : Kapasitas (smp/jam)

Q. smp = arus total yang sesungguhnya (smp/jam) yang dihitung dengan

Q.smp = Q. kendaraan $\mathrm{x}$ Fsmp sehingga :

$\mathrm{Q}=\left(\mathrm{emp} \mathrm{L}_{\mathrm{V}} \times \mathrm{L}_{\mathrm{V}}(\mathrm{kend} / \mathrm{jam})+\mathrm{emp} \mathrm{H}_{\mathrm{V}} \times \mathrm{H}_{\mathrm{V}}(\mathrm{kend} / \mathrm{jam})+\mathrm{emp} \mathrm{M}_{\mathrm{c}} \times\left(\mathrm{M}_{\mathrm{c}} \mathrm{kend} / \mathrm{jam}\right)\right.$

Untuk nilai emp, masing-masing kendaraan didapat dari tabel emp,

\section{Tingkat Pelayanan Trotoar dan Jenis Fasilitas Penyeberang Jalan.}

$\underline{\text { Tingkat Pelayanan Trotoar. }}$

Tingkat pelayanan trotoar digunakan standar dariHighway Capacity Manual (HCM) 1985

$$
W e=\frac{V}{15 . v}
$$

Di mana

$$
\begin{array}{lll}
\mathrm{We} & \text { Lebar efektif Trotoar }(\mathrm{m}) \\
\mathrm{V}: \text { Arus maksimum Pejalan kaki (Orang/15 menit) } \\
\mathrm{v}: \text { Arus rata-rata Pejalan kaki (Orang/menit/meter) }
\end{array}
$$

Jenis Fasilitas Penyeberang Jalan.

Jenis fasilitas Penyeberang Jalan digunakan standar dari Ditjen Bina Marga (1999)

$$
\mathrm{PV}^{2}
$$


Di mana

$\mathrm{P} \quad$ : Arus pejalan kaki yang menyeberang jalan $($ Orang/jam/100 m)

$\mathrm{V}$ : Arus lalu lintas kendaraan dua arah (kendaraan/jam)

\subsection{Manajemen Lalu lintas dan Local Area Traffic Management ( LATM)}

Manajemen lalu lintas meliputi kegiatan pe-rencanaan, pengaturan, pengawasan dan pengendalian lalu lintas.Kegiatan perenca-naan lalu lintas meliputi inventarisasi dan evaluasi tingkat pelayanan, penetapan ting-kat pelayanan yang diinginkan, penetapan pemecahan permasalahan lalu lintas dan penyusunan program pelaksa-naan.Sedangkan kegiatan pengaturan lalu lintas meliputi kegiatan penetapan kebijak-sanaan lalu lintas pada jaringan atau ruas - ruas jalan tertentu.(Pasal 2 Peraturan Peme-rintah No. 43 Tahun 1993 tentang Prasarana dan Lalu Lintas Jalan).

Local Area Traffic Management( LATM) adalahsuatu pengaturan pertemuan lalu lintas sebidang antara dua atau lebih ruas jalan pada suatu area tertentu untuk meningkatkan kinerja pergerakan lalu lintas dan meningkatkan keselamatan lalu lintas dan mengatasi kemacetan dan konflik lalu lintas pada persimpangan. Dari beberapa study/penelitian penanganan Local Area Traffic Management( LATM) yang telah di-lakukan antara lain sebagai berikut :

1. Local Area Traffic Management (LATM) jalan Pakubuwono Jakarta Selatan yaitu dengan melakukan beberapa pengaturan sederhana melarang arus lalu lintas belok kanan, memperbaiki geome-trik simpang, membuat pulau lalu lin-tas/pulau pengarah dan perobahan pada median jalan.

2. Local Area Traffic Management(LATM) pada kawasan pemukiman kota Wyndham, dilakukan untuk menekan angka kecelakaan lalu lintas dan aksi ke-but-kebutan berupa pembatasan kecepa-tan.

3. Local Area Traffic Management(LATM) kota Bribane dengan melakukan efisiensi mode dan rute untuk meminimalkan dampak lalu lintas pada lingkungan perumahan.

4. Local Area Traffic Management(LATM) kota Charles Sturt dengan menentukan beberapa ruas jalan dalam kota menjadi jalan satu arah untuk meminimalisir kemacetan lalu lintas dalam kota.

5. Local Area Traffic Management(LATM) kota Sydney melakukan modifikasi persimpangan dan memberi prioritas lalu lintas pada jalan utama.

\section{METODOLOGI}

Metodologi yang dilakukan dalam penelitian ini dapat dilihat dalam bentuk gambar bagan alir pada Gambar 1

\subsection{Survey Pendahuluan.}

Survey pendahuluan ini dilakukan untuk mengamati arus lalu lintas yang terjadi pada ruas jalan Gajah Mada Kota Padang Berda-sarkan hasil pengamatan terhadap pengguna angkutan umum dan pribadi ditetapkan pa-rameter yang akan digunakan, yaitu arus lalu lintas, derajat kejenuhan, kecepatan waktu tempuh dan tingkat pelayanan kendaraan dan pejalan kaki (Penyeberang Jalan).

Gambar. 2. merupakan lokasi penelitian/survey yaitu 1) simpang Jl Gajah Mada - Jl STKIP PGRI, 2) simpang Jl Gajah Mada - Jl Perumahan Tabiang Banda Gadangdan 3) SimpangJl Peruma-han Tabiang Banda Gadang - J1 STKIP PGRI.yang menggambarkan sirkulasi arus keluarmasuk kendaraanmenuju kawasan pendidikan dan pemukiman pada ruas jalan Gajah Mada kota Padang. 


\subsection{Pengumpulan data.}

Dalam penelitian ini digunakan data primer dan data sekunder. Data primer adalah data yang diperoleh seca-ra langsung di lapangan anatara lain berupa Volume lalu lintas, dan Volume pejalan kaki (Penyeberang jalan). Data sekunder yang digunakan dalam peneli-tian ini antara lain Peta Kota Padang, Peta Jaringan Jalan, Tata Ruang Kawasan Study. Data ini diperoleh dari Instansi terkait seperti : Dinas Perhubungan Kota Padang, Dinas Pekerjaan Umum Kota Padang, Bappeda Ko-ta Padang, dan BPS Kota Padang.

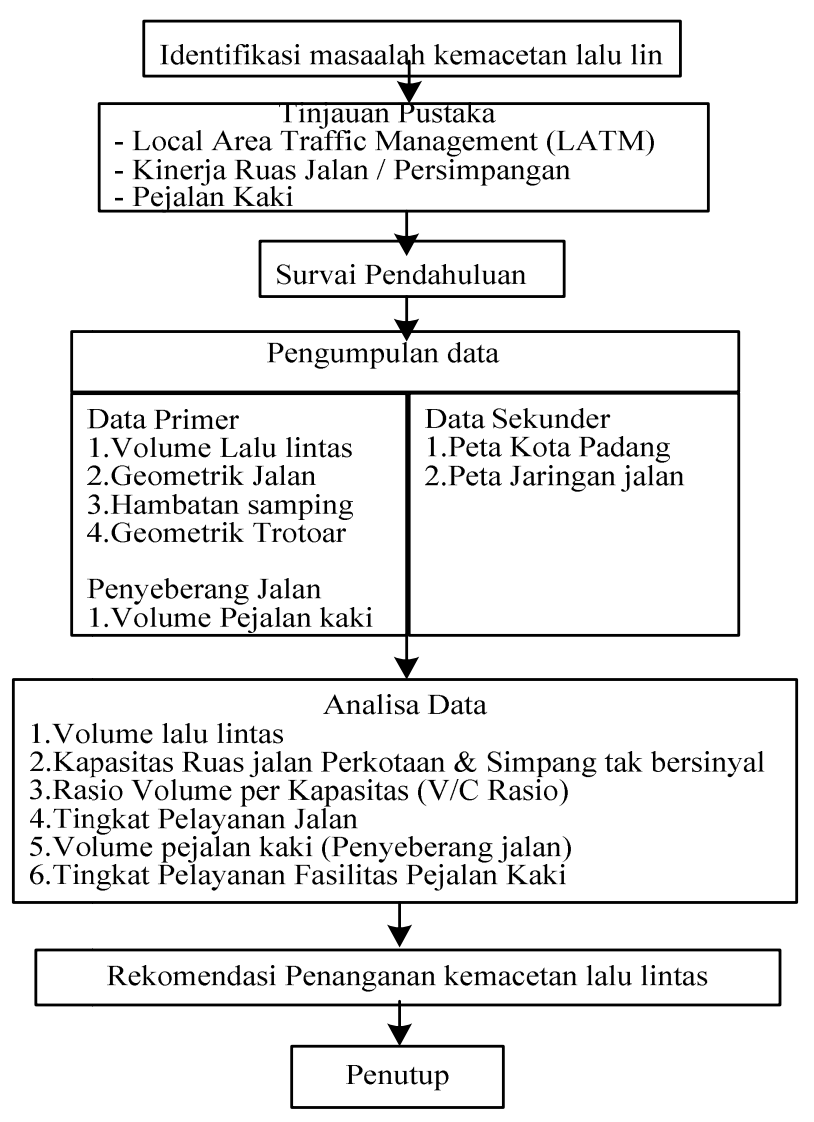

Gambar. 1 Bagan Alir Metodologi Penelitian

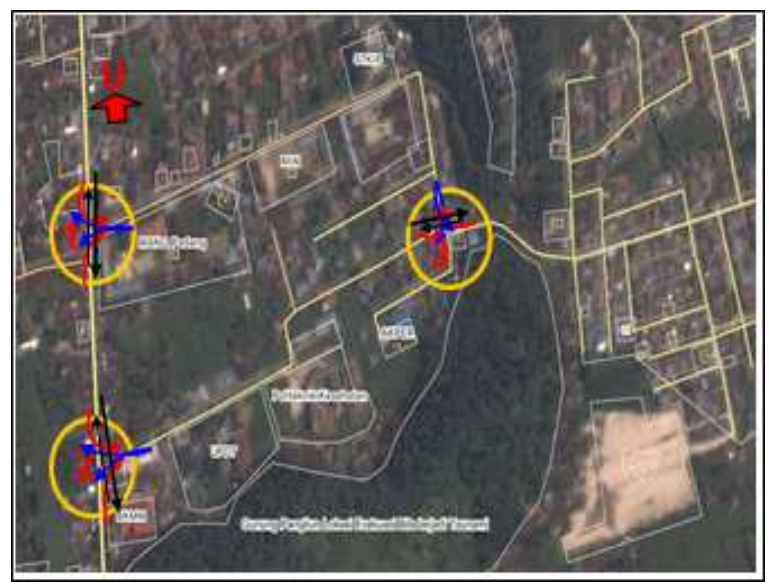


Gambar. 2. Lokasi Penelitian

\section{HASIL DAN PEMBAHASAN}

\subsection{Hasil Survey}

Hasil Survey lalu lintas yang dilaksanakan selama tiga hari yaitu hari Sabtu, Minggu dan Senin pada tiga lokasi survey dapat dilihat pada Tabel. 1

Tabel. 1. Hasil Survey Volume Lalu lintas

\begin{tabular}{|c|c|c|c|c|c|c|c|c|c|c|c|c|c|c|c|c|c|c|c|c|}
\hline \multirow{4}{*}{$\begin{array}{c}\text { Hari } \\
\text { Inowd }\end{array}$} & \multicolumn{7}{|c|}{ 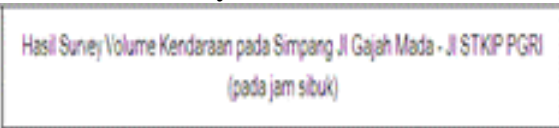 } & \multicolumn{7}{|c|}{ 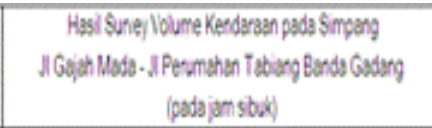 } & \multicolumn{6}{|c|}{ 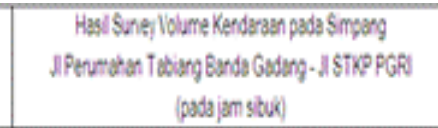 } \\
\hline & \multirow[t]{3}{*}{ 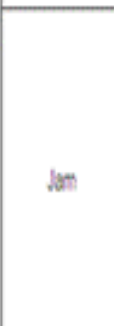 } & \multicolumn{2}{|c|}{ Dais Steto } & \multicolumn{2}{|c|}{ Dan $\mathrm{H}_{\mathrm{B}}$} & \multicolumn{2}{|c|}{ DaisTKP } & \multicolumn{2}{|c|}{ Dris Stebo } & \multicolumn{2}{|c|}{ Dan ha } & \multicolumn{3}{|c|}{ Dri WFEER } & \multicolumn{2}{|c|}{$\mathrm{Drin} \mathrm{BPOM}$} & \multicolumn{2}{|c|}{ Dasi fermm Trobarg } & \multicolumn{2}{|c|}{ DrisTKP } \\
\hline & & insis & $\begin{array}{l}\text { Boukn } \\
\text { iestop }\end{array}$ & $\begin{array}{l}\text { Lunig } \\
\text { SECS }\end{array}$ & $\begin{array}{c}\text { Bad } \\
\text { kent is } \\
\text { sthe }\end{array}$ & 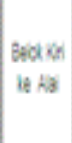 & $\begin{array}{l}\text { Bad } \\
\text { Karstit } \\
\text { State }\end{array}$ & $\begin{array}{c}\text { insig } \\
\text { has }\end{array}$ & $\begin{array}{l}\text { Bad ist } \\
\text { ia ANGer }\end{array}$ & $\begin{array}{l}\text { Lusis } \\
\text { SAEs }\end{array}$ & 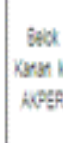 & ind & & $\begin{array}{l}\text { Beod } \\
\text { sestit } \\
\text { seas }\end{array}$ & 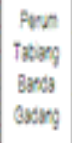 & $\sin 0^{\circ}$ & $\begin{array}{c}P 0 \mathrm{~W} \\
\mathrm{set}\end{array}$ & step & 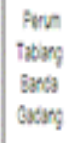 & $\begin{array}{l}\text { BOW } \\
\text { Suts }\end{array}$ \\
\hline & & & & & & $3 m$ & smpjam & smolari) & (smplami & smpjem & $\operatorname{smp} / \mathrm{ar}$ & $m p$ & & mpigmi & $(\operatorname{smp} \mid a n)$ & smpjams & mplamiti & 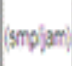 & strpjam & smpiam \\
\hline \multirow{2}{*}{$\begin{array}{l}\text { Sect } 02 \\
\text { Merel } 2013\end{array}$} & $W+4$ & 8738 & 912 & 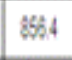 & 8 & 1069 & $11 \% 1$ & 898 & 410 & 869 & 139 & 246 & & 785 & $148 \mathrm{C}$ & 21 & 2018 & $10 \% 3$ & 1380 & 613 \\
\hline & 1600.17 & 862 & 1108 & 8000 & 892 & 1169 & 1307 & 8185 & 540 & 866 & 6. 1306 & 155 & & 505 & 2013 & 520 & 1445 & 1285 & 160.5 & 520 \\
\hline \multirow{2}{*}{$\begin{array}{l}\text { Nergy } 03 \\
\text { Mereat2013 }\end{array}$} & 40 & 5 & 1355 & 3 & 1402 & 168.1 & 121.4 & 5514 & 340 & 502 & 590 & 92 & & $5 \%$ & 1755 & 786 & 2078 & 838 & 1620 & 728 \\
\hline & $18.45 \cdot 17.45$ & 325 & 1225 & 3020 & 482 & 1489 & 1008 & 4338 & 608 & 402 & 51.1 & 74 & & 472 & 1883 & 415 & 1690 & 1215 & 1605 & 40 \\
\hline \multirow{2}{*}{$\begin{array}{l}\text { Serin } 04 \\
\text { Wart } 2013\end{array}$} & $03.45 \cdot 07.45$ & 7784 & 1280 & 764.1 & 1165 & 1422 & 131.1 & 8114 & 500 & 784 & 1250 & 250 & & 68 & 245 & 181.1 & 2778 & 1803 & 1740 & 1506 \\
\hline & 1615.17 .15 & 800.4 & 888 & 8210 & 1213 & 1798 & 1263 & 8168 & 510 & 807 & 1601 & 102 & & 57.6 & 2158 & 1048 & 2285 & 106.1 & 880 & 784 \\
\hline
\end{tabular}

\subsection{Analisa dan Pembahasan}

Analisa Volume Lalu lintas (QTOT) pada simpang Jl Gajah Mada - Jl STKIP PGRIyaitu hasil perkalian jumlah kendaraan menurut jenis dengan faktor smp/jam pada jam puncak hari Sabtu jam $07.00-08.00$ dapat dilihat pada Tabel .2 berikut.

Tabel. 2 Hasil analisa QTOT Simpang Jl Gajah Mada - Jl STKIP PGRI

Pada jam puncak hari Sabtu jam $07.00-08.00$ 


\begin{tabular}{|c|c|c|c|c|c|c|c|c|c|}
\hline \multirow{3}{*}{ Arus Lalu Lintas } & \multirow{3}{*}{ Arah } & \multicolumn{2}{|c|}{ Kendaraan ringan LV } & \multicolumn{2}{|c|}{ Kendaraan berat $\mathrm{HV}$} & \multicolumn{2}{|c|}{ Sepeda Motor } & \multicolumn{2}{|c|}{$\begin{array}{c}\text { Kendaraan bermotor } \\
\text { total MV }\end{array}$} \\
\hline & & \multirow{2}{*}{ Kend/jam } & 1 & \multirow[b]{2}{*}{ Kend/jam } & \multirow{2}{*}{$\begin{array}{c}1.3 \\
\text { smp/jam }\end{array}$} & \multirow{2}{*}{ Kend/jam } & \multirow{2}{*}{$\begin{array}{c}0.5 \\
\text { smp/jam }\end{array}$} & \multirow{2}{*}{ kend/jam } & \multirow[b]{2}{*}{ smp/jam } \\
\hline & & & smp/jam & & & & & & \\
\hline (1) & (2) & (3) & (4) & (5) & (6) & (7) & (8) & (9) & (10) \\
\hline \multirow{4}{*}{$\begin{array}{l}\text { Jl Minor C } \\
\text { JIn STKIP }\end{array}$} & $\mathrm{LT}$ & 31.0 & 31.0 & 3.0 & 3.9 & 144.0 & 72.0 & 178.0 & 106.9 \\
\hline & ST & & & & & & & & \\
\hline & RT & 23.0 & 23.0 & 7.0 & 9.1 & 168.0 & 84.0 & 198.0 & 116.1 \\
\hline & Total & 54.0 & 54.0 & 10.0 & 13.0 & 312.0 & 156.0 & 376.0 & 223.0 \\
\hline JI Utama (B) & LT & 34.0 & 34.0 & 4.0 & 5.2 & 104.0 & 52.0 & 142.0 & 91.2 \\
\hline \multirow[t]{3}{*}{ Siteba - Alai } & ST & 297.0 & 297.0 & 21.0 & 27.3 & $1,099.0$ & 549.5 & $1,417.0$ & 873.8 \\
\hline & RT & & & & & & & & \\
\hline & Total & 331.0 & 331.0 & 25.0 & 32.5 & $1,203.0$ & 601.5 & $1,559.0$ & 965.0 \\
\hline Jl utama (D) & $\mathrm{LT}$ & & & & & & & & \\
\hline \multirow[t]{3}{*}{ Alai - Siteba } & ST & 315.0 & 315.0 & 8.0 & 10.4 & $1,062.0$ & 531.0 & $1,385.0$ & 856.4 \\
\hline & RT & 19.0 & 19.0 & 5.0 & 6.5 & 110.0 & 55.0 & 134.0 & 80.5 \\
\hline & Total & 334.0 & 996.0 & 63.0 & 81.9 & $3,578.0$ & $1,789.0$ & $4,637.0$ & $2,866.9$ \\
\hline \multirow[t]{4}{*}{ JI Utama total B + D } & & 665.0 & $1,327.0$ & 88.0 & 114.4 & $4,781.0$ & $2,390.5$ & $6,196.0$ & $3,831.9$ \\
\hline & LT & 65.0 & 65.0 & 7.0 & 9.1 & 248.0 & 124.0 & 320.0 & 198.1 \\
\hline & ST & 612.0 & 612.0 & 29.0 & 37.7 & $2,161.0$ & $1,080.5$ & $2,802.0$ & $1,730.2$ \\
\hline & RT & 42.0 & 42.0 & 12.0 & 15.6 & 278.0 & 139.0 & 332.0 & 196.6 \\
\hline Utama + Minor total & & 719.0 & 719.0 & 48.0 & 62.4 & 2.687 .0 & 1.343 .5 & 3.454 .0 & 2.124 .9 \\
\hline
\end{tabular}

Dari hasil analisa didapat $\mathrm{Q}_{\text {тот }}$ simpang Jl Gajah Mada - Jl STKIP PGRI pada jam puncak hari Sabtu jam 07.00 - 08.00 sebesar 2.124,9 smp/jam. Kapasitas Simpang tak bersinyal (C )dihitung menurut Rumus (1). Hasil perhitungan Kapasitas Simpang dapat dilihat pada Tabel. 3

Tabel. 3. Hasil Perhitungan Kapasitas simpangJl Gajah Mada - Jl STKIP PGRI

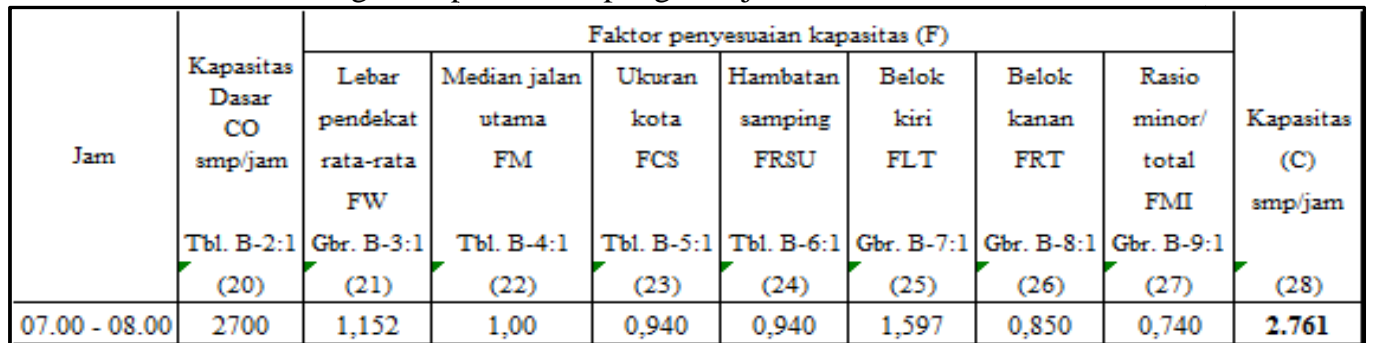

Dari Tabel B-2.1 Direktur Jenderal Bina Marga, 1997 "Manual Kapasitas Jalan Indonesia"(MKJI)untuk tipe simpang 322 didapat Kapasitas dasar $\left(\mathrm{C}_{0}\right)=2700 \mathrm{smp} / \mathrm{jam}$. Dari hasil analisa didapat $(\mathrm{C})=2.739 \mathrm{smp} / \mathrm{jam}$.

\section{Derajat Kejenuhan}

Perhitungan derajat kejenuhan (DS) dihitung berdasarkan persamaan (3). Hasil analisa Derajat Kejenuhan dapat dilihat pada Tabel.4.

Tabel.4 Hasil analisa Derajat Kejenuhan

\begin{tabular}{|c|c|c|c|c|c|c|c|c|}
\hline Jam & $\begin{array}{l}\text { Arus lalu- } \\
\text { lintas (Q) } \\
\text { smp/jam }\end{array}$ & $\begin{array}{c}\text { Derajat } \\
\text { kejenuhan } \\
\text { (DS) } \\
\text { Q/C }\end{array}$ & $\begin{array}{c}\text { Tundaan lalu } \\
\text { lintas } \\
\text { simpang } \\
\text { (detik) DT } \mathrm{I}\end{array}$ & $\begin{array}{c}\text { Tundaan } \\
\text { lalu lintas } \\
\text { JI.Utama } \\
\text { (detik) D } \mathrm{D}_{\mathrm{MA}}\end{array}$ & $\begin{array}{l}\text { Tundaan } \\
\text { lalu lintas } \\
\text { JI.Minor } \\
\text { (detik) D } D_{\mathrm{MI}}\end{array}$ & $\begin{array}{c}\text { Tundaan } \\
\text { geometric } \\
\text { simpang } \\
\text { (detik) (DG) }\end{array}$ & $\begin{array}{c}\text { Tundaan } \\
\text { simpang } \\
\text { (detik) (D) }\end{array}$ & $\begin{array}{c}\text { Indek } \\
\text { Tingkat } \\
\text { Pelayanan } \\
\text { (ITP }\end{array}$ \\
\hline $07.00-08.00$ & 2,125 & 0.78 & 8.62 & 6.37 & 14.99 & 4.11 & 12.74 & $\mathrm{D}$ \\
\hline
\end{tabular}

Dari hasil perhitungan didapat DS $=0,78$. Analisa Volume Lalu lintas $\left(\mathrm{Q}_{\mathrm{TOT}}\right)$ pada simpang $\mathrm{Jl}$ Gajah Mada - Jl Perumahan Tabiang Banda Gadang yaitu hasil perkalian jumlah kendaraan menurut jenis dengan faktor smp/jam pada jam puncak hari Sabtu jam $06.45-07.45$ dapat dilihat pada Tabel .5.

Tabel. 5 Hasil analisa QTOT Simpang Jl Gajah Mada - Jl Perumahan Tabiang Banda gadang Pada jam puncak hari Sabtu jam $06.45-07.45$ 


\begin{tabular}{|c|c|c|c|c|c|c|c|c|c|}
\hline \multirow[t]{2}{*}{ Arus Lalu Lintas } & \multirow[t]{2}{*}{ Arah } & \multicolumn{2}{|c|}{ Kendaraan ringan LV } & \multicolumn{2}{|c|}{ Kendaraan berat $\mathrm{HV}$} & \multicolumn{2}{|c|}{ Sepeda Motor } & \multicolumn{2}{|c|}{$\begin{array}{c}\text { Kendaraan bermotor } \\
\text { total MV }\end{array}$} \\
\hline & & Kend/jam & 1 & Kend/jam & 1.3 & Kend/jam & 0.5 & kend/jam & smp/jam \\
\hline & & & smp/jam & & smp/jam & & smp/jam & & \\
\hline (1) & (2) & (3) & (4) & (5) & (6) & (7) & (8) & (9) & (10) \\
\hline Jl Minor C & $\mathrm{LT}$ & 123 & 123 & 2 & 2.6 & 268 & 134 & 393 & 260 \\
\hline \multirow[t]{3}{*}{$\begin{array}{l}\text { Jin Perumahan Tabiang Banda } \\
\text { Gadang }\end{array}$} & ST & & & & & & & & \\
\hline & RT & 37 & 37 & 1 & 1.3 & 95 & 47.5 & 133 & 86 \\
\hline & Total & 160 & 160 & 3 & 3.9 & 363 & 181.5 & 526 & 345 \\
\hline JI Utama (B) & LT & 12 & 12 & 0 & 0 & 71 & 35.5 & 83 & 48 \\
\hline \multirow[t]{3}{*}{ Siteba - Alai } & ST & 297 & 297 & 10 & 13 & 914 & 457 & 1221 & 767 \\
\hline & RT & & & & & & & & \\
\hline & Total & 309 & 309 & 10 & 13 & 985 & 492.5 & 1304 & 814.5 \\
\hline Jl utama (D) & $\mathrm{LT}$ & & & & & & & & \\
\hline \multirow[t]{3}{*}{ Alai - Siteba } & ST & 320 & 320 & 9 & 11.7 & 915 & 457.5 & 1244 & 789 \\
\hline & RT & 30 & 30 & 0 & 0 & 189 & 94.5 & 219 & 125 \\
\hline & Total & 350 & 968 & 29 & 37.7 & 3074 & 1537 & 4071 & 2543 \\
\hline JI Utama total B + D & & 659 & 1277 & 39 & 50.7 & 4059 & 2029.5 & 5375 & 3357 \\
\hline \multirow[t]{3}{*}{ Utama + Minor } & LT & 135 & 135 & 2 & 2.6 & 339 & 169.5 & 476 & 307 \\
\hline & ST & 617 & 617 & 19 & 24.7 & 1829 & 914.5 & 2465 & 1556 \\
\hline & RT & 67 & 67 & 1 & 1.3 & 284 & 142 & 352 & 210 \\
\hline Utama + Minor total & & 819 & 819 & 22 & 28.6 & 2452 & 1226 & 3293 & 2074 \\
\hline
\end{tabular}

Tabel. 6. Hasil Perhitungan Kapasitas simpang

\begin{tabular}{|c|c|c|c|c|c|c|c|c|c|}
\hline \multirow{3}{*}{ Jam } & \multirow{3}{*}{$\begin{array}{c}\text { Kapasitas } \\
\text { Dasar } \\
\text { C0 } \\
\text { smp/jam } \\
\text { Tbl. B-2:1 }\end{array}$} & \multicolumn{7}{|c|}{ Faktor penyesuaian kapasitas (F) } & \multirow{3}{*}{$\begin{array}{c}\text { Kapasitas(C) } \\
\text { smp/jam }\end{array}$} \\
\hline & & $\begin{array}{c}\text { Lebar } \\
\text { pendekat } \\
\text { rata-rata } \\
\left(\mathrm{F}_{\mathrm{W}}\right)\end{array}$ & $\begin{array}{c}\text { Median } \\
\text { jalan } \\
\text { Utama } \\
\left(\mathrm{F}_{\mathrm{M}}\right)\end{array}$ & $\begin{array}{l}\text { Ukuran } \\
\text { kota } F_{C s}\end{array}$ & $\begin{array}{c}\text { Hambatan } \\
\text { samping } \\
\text { F }_{\text {RSU }}\end{array}$ & $\begin{array}{l}\text { Belok kiri } \\
\mathrm{F}_{\mathrm{LT}}\end{array}$ & $\begin{array}{c}\text { Belok } \\
\text { kanan } \mathrm{F}_{\mathrm{RT}}\end{array}$ & $\begin{array}{l}\text { Rasio } \\
\text { minor/ } \\
\text { total FMI }\end{array}$ & \\
\hline & & Gbr. B-3:1 & Tbl. B-4:1 & Tbl. B-5:1 & Tbl. B-6:1 & Gbr. B-7:1 & Gbr. B-8:1 & Gbr. B-9:1 & \\
\hline
\end{tabular}

Perhitungan Volume Lalu lintas per jam pada pada ruas jalan dari simpang Jl Gajah Mada - Jl STKIP PGRIsampai simpang Jl Gajah Mada - Jl Perumahan Tabiang Banda Gadang (dua arah pp)

Tabel.5. Hasil analisa hari Sabtu, ; Jam Puncak =06.45-07.45 WIB

\begin{tabular}{|c|c|c|c|c|c|c|c|c|}
\hline \multirow{3}{*}{ Jam } & \multicolumn{2}{|c|}{ Kend. Ringan } & \multicolumn{2}{|c|}{ Kend. Berat } & \multicolumn{2}{|c|}{ Kend. Motor } & \multirow{2}{*}{\multicolumn{2}{|c|}{ Arus Total 0}} \\
\hline & $\mathrm{LV}$ & 1 & $\mathrm{HV}$ & 1.2 & $\mathrm{MC}$ & 0.25 & & \\
\hline & Kend/ Jam & Smp/Jam & Kend/Jam & Smpl/Jam & Kend/ Jam & Smpl/Jam & Kend/ Jam & Smp/lam \\
\hline $06.45-07.45$ & 689.0 & 689.0 & 25.0 & 30.00 & $2,135.0$ & 533.75 & $2,849,0$ & $1,252.75$ \\
\hline
\end{tabular}

\section{Kapasitas Ruas Jalan}

Kapasitas Ruas Jalan dihitung dengan menggunakan persamaan (2).

Tabel.6. Hasil analisahari Sabtu, Jam Puncak $=06.45-07.45$ WIB (dua arah pp)

\begin{tabular}{|c|c|c|c|c|c|c|c|c|c|}
\hline \multirow[b]{2}{*}{ Jam } & \multirow[b]{2}{*}{$\begin{array}{c}\text { Kapasitas } \\
\text { Dasar CO } \\
\text { smpljam } \\
\text { Tbl. B-2:1 }\end{array}$} & \multicolumn{7}{|c|}{ Faktor penyesuaian kapasitas $(\mathrm{F})$} & \multirow[b]{2}{*}{$\begin{array}{c}\text { Kapasitas(C) } \\
\text { smp/jam }\end{array}$} \\
\hline & & $\begin{array}{c}\text { Lebar } \\
\text { pendekat } \\
\text { rata-rata }\left(\mathrm{F}_{\mathrm{W}}\right) \\
\text { Gbr. } \mathrm{B}-3: 1\end{array}$ & $\begin{array}{l}\text { Median jalan } \\
\text { Utama }\left(\mathrm{F}_{\mathrm{M}}\right) \\
\text { Tbl. B-4:1 }\end{array}$ & $\begin{array}{l}\text { Ukuran kota } \\
\qquad \text { FCS } \\
\text { Tbl. B-5:1 }\end{array}$ & $\begin{array}{c}\text { Hambatan } \\
\text { samping } F_{\text {RSU }} \\
\text { Tbl. B-6:1 }\end{array}$ & $\begin{array}{l}\text { Belok kiri } \\
\qquad F_{\text {LT }} \\
\text { Gbr. B-7:1 }\end{array}$ & $\begin{array}{c}\text { Belok kanan } \\
\text { FRT }_{\text {RT }} \\
\text { Gbr. B-8:1 }\end{array}$ & $\begin{array}{c}\text { Rasio minor/ } \\
\text { total F } \\
\text { Gbr. B-9:1 }\end{array}$ & \\
\hline $06.45-07.45$ & 2700 & 1.152 & 1.00 & 0.940 & 0.940 & 1.597 & 0.850 & 0.734 & 2.739 \\
\hline
\end{tabular}

Hasil analisa Derajat kejenuhan Ruas jalan dapat dilihat pada Tabel 7.berikut.

Tabel.7. Hasil analisa derajat kejenuhan hari Sabtu, ; Jam Puncak =06.45-07.45 WIB (dua arah pp) 


\begin{tabular}{|c|c|c|c|c|c|c|c|c|c|c|c|}
\hline \multirow{3}{*}{ Jam } & \multirow{2}{*}{\multicolumn{2}{|c|}{$\frac{\text { Sepeda Motor }}{\mathrm{MC}}$}} & \multirow{2}{*}{\multicolumn{2}{|c|}{$\begin{array}{c}\text { Kend. Ringan } \\
\text { LV }\end{array}$}} & \multirow{2}{*}{\multicolumn{2}{|c|}{$\frac{\text { Kend. Berat }}{\mathrm{HV}}$}} & \multirow{2}{*}{\multicolumn{2}{|c|}{ Arus Total Q }} & Kapasit & \multirow{3}{*}{$\begin{array}{c}\text { Derajat } \\
\text { Kejenuhan }\end{array}$} & \multirow{3}{*}{$\begin{array}{c}\text { Tingkat } \\
\text { Pelayanan }\end{array}$} \\
\hline & & & & & & & & & as & & \\
\hline & $\begin{array}{l}\text { Kend/ } \\
\text { Jam }\end{array}$ & $\begin{array}{c}\text { Smp/Jam } \\
0.25\end{array}$ & $\begin{array}{c}\text { Kend/ } \\
\text { Jam }\end{array}$ & $\begin{array}{c}\text { Smp/Jam } \\
1\end{array}$ & $\begin{array}{c}\text { Kend/ } \\
\text { Jam }\end{array}$ & $\begin{array}{c}\text { Smp/Jam } \\
1.2\end{array}$ & Kend/Jam & Smp/Jam & $\begin{array}{c}\text { smp/ja } \\
\mathrm{m}\end{array}$ & & \\
\hline $06.45-07.45$ & 2,135 & 533.8 & 689 & 689 & 25 & 30 & 2,849 & $1,252.8$ & 2,344 & 0.53 & C \\
\hline
\end{tabular}

Hasil lengkap analisa kapasitas (Q), derajat kejenuhan (DS) pada simpang dan ruas jalan yang ditinjau dapat dilihat pada Gambar 2. Hasil Survey Pejalan kaki/penyeberang jalan pada (Trotoar dan Penyeberang jalan) depan MAN 2 Padang dapat dilihat pada Tabel 8

\section{Tingkat Pelayanan Trotoar}

Dari data survei arus rata-rata pejalan kaki selama 15 menit didapatkan sebanyak 37 orang pejalan kaki. Dan lebar existing trotoar : $150 \mathrm{~cm}$ atau $1,5 \mathrm{~m}$. Untuk mendapatkan tingkat pelayanan existing trotoar digunakan persamaan (4). Jadi :

$$
\begin{aligned}
& 1,50=\frac{37}{15 \times v} \\
& v=\frac{37}{1,50 \times 15}=1,6 \mathrm{org} / \mathrm{menit} / \mathrm{meter}
\end{aligned}
$$

$v=1,6$ Orang/meter/menit (Standar Tingkat Pelayanan Trotoar berdasarkan Highway Capacity Manual (HCM) 1985dengan tingkat pelayanan A yaitu $\leq 7$ 0rg/meter/menit)

Tabel 8. : Arus pejalan kaki

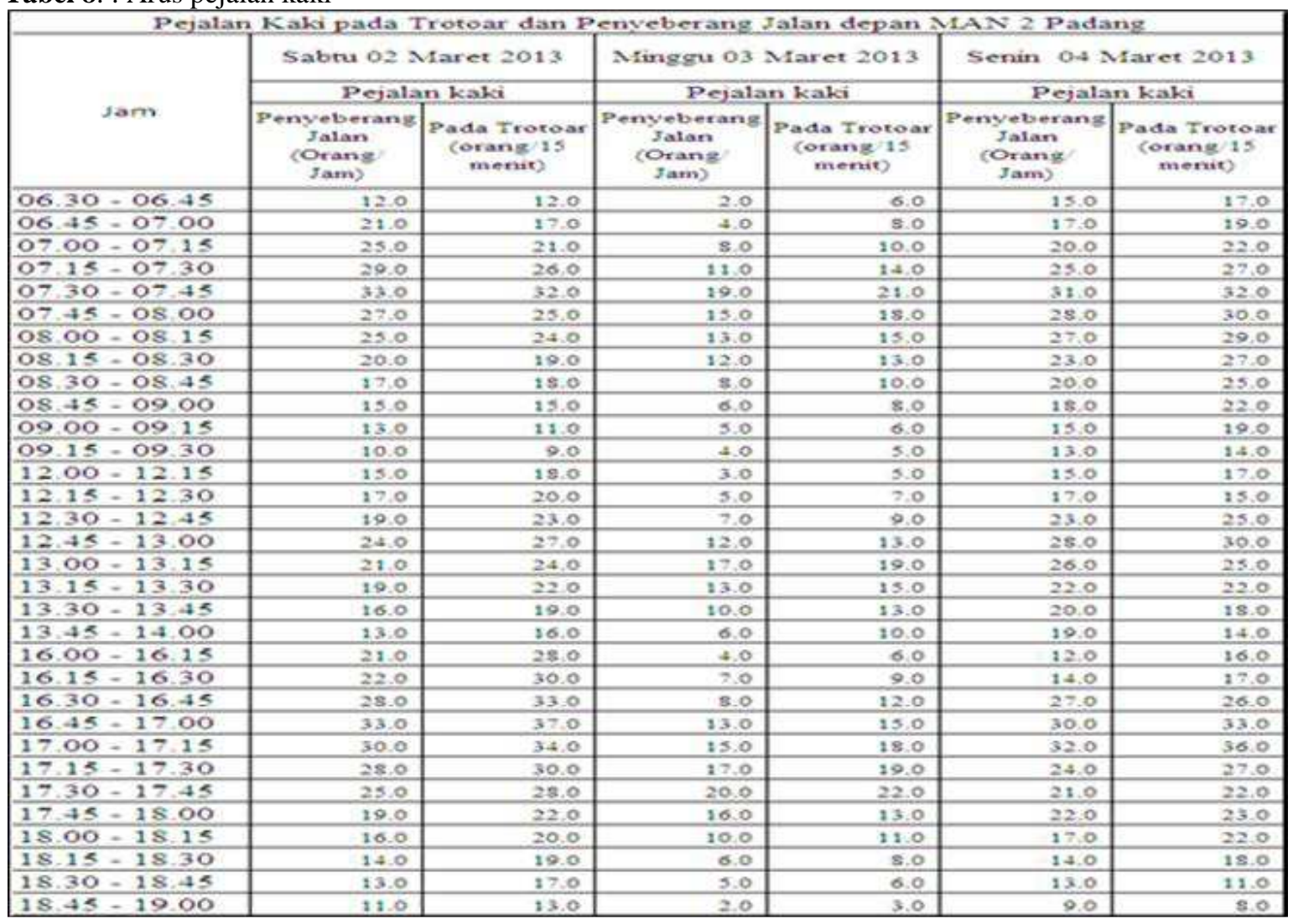

Jenis Fasilitas Penyeberang Jalan 
Dari data survei volume kendaraan dan aruspejalan kaki/penyeberang jalanpada 4 (empat) jam puncak didapatkan sebagaimana Tabel 9. Untuk mendapatkan Jenis Fasilitas Penyeberang Jalan digunakan persamaan (5).

Di mana

$\mathrm{P}=$ Arus pejalan kaki yang menyeberang jalan $($ Orang/jam/100 m)

$\mathrm{V}=$ Arus lalu lintas kendaraan dua arah (kendaraan/jam)

Tabel. 9 Volume Kendaraan dan Penyeberang jalan pada empat (4) jam puncak

\begin{tabular}{|l|l|l|l|}
\hline Jam & $\mathrm{P}($ org/jam $)$ & $\mathrm{V}(\mathrm{kend} / \mathrm{jam})$ & $\mathrm{PV} 2$ \\
\hline $07.00-08.00$ & 114 & 3.037 & \\
\hline $18.00-09.00$ & 77 & 2.119 & \\
\hline $16.00-17.00$ & 104 & 2,707 & \\
\hline $17.00-18.00$ & 102 & 1.913 & \\
\hline
\end{tabular}

$\mathrm{P}=(114+77+104+102) / 4=99,25$

$\mathrm{V}=(3.037+2.119+2.707+1.913) / 4=2.444$

$\mathrm{PV}^{2}=99,25 \times 2.444^{2}=59,3 \times 10^{8}$

$\mathrm{P}=50-1.100$ Orang/jam/100 meter (Jenis Fasilitas Penyeberangan berdasarkan pedoman perencanaan jalur pejalan kaki pada Jalan umum Direktur Jenderal Bina Marga 1999 Zebra Cross)

\section{Local Area Traffic Management ( LATM)}

Rencana Skema penanganan manajemen lalu lintas kawasan pendidikan, pemukiman dan perkantoran antara simpang Jl Gajah Mada - Jl STKI PGRI dan simpang Jl.Gajah Mada - Jl Perumahan Tabiang Banda Gadang(Local Area Traffic Management)sepeti Gambar 3.

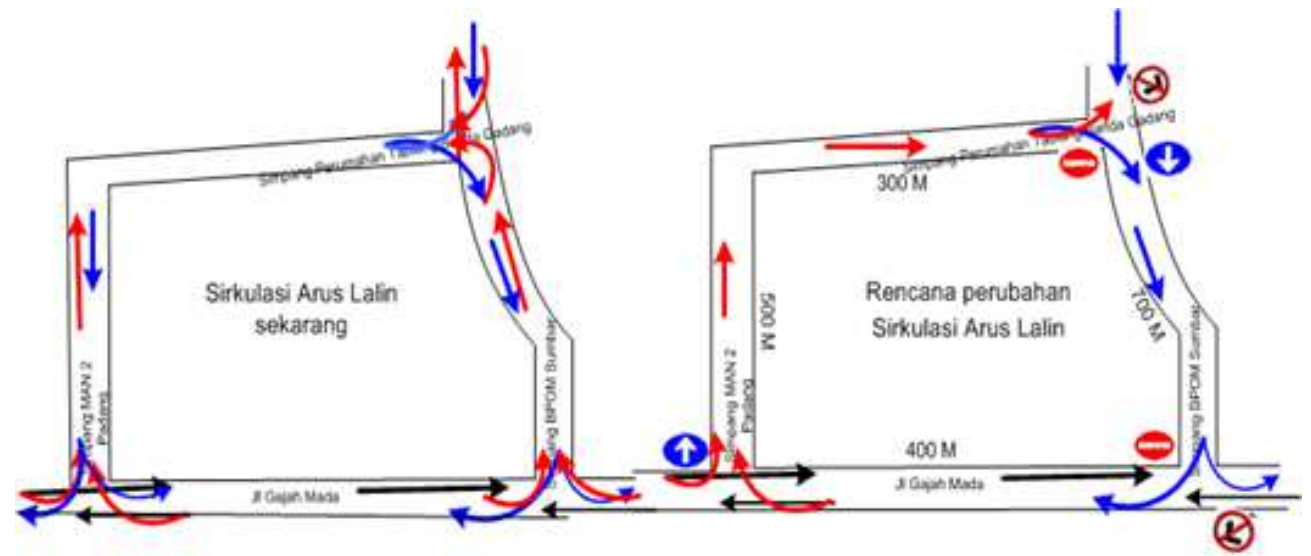

Gambar 3. Sirkulasi arus lalu lintas dan perambuan pada kawasan pendidikan dan pemukiman

Tabel 10 Perbandingan Tingkat Pelayanan Simpang Tak Bersinyal Simpang Jl. Gajah Mada - Simpang STKIP PGRI (Simpang MAN 2 Padang) 


\section{Perbandingan Tingkat Pelayanan Simpang Tak Bersinyal}

pada Simpang JL Gajah Mada - JL STKIP PGRI antara keadaan sekarang (Existing) dengan Alternatif yang diusulkan pada jam sibuk

\begin{tabular}{|c|c|c|c|c|c|c|c|c|c|c|c|c|c|c|c|c|c|c|}
\hline & & & & & isting & & & & & & & & & komend & & & & \\
\hline Jam & $\begin{array}{l}\text { Arus lalu- } \\
\text { lintas (Q) } \\
\text { smp jaml } \\
\text { USIG.I }\end{array}$ & $\begin{array}{l}\text { Capasitas } \\
\text { (C) } \\
\text { smp jam }\end{array}$ & $\begin{array}{c}\text { Derajat } \\
\text { kejenuhan } \\
\text { (DS) }\end{array}$ & \begin{tabular}{|c|} 
Tundaan \\
lalu- \\
lintas \\
simpang \\
(detili) \\
DII \\
\end{tabular} & $\begin{array}{c}\text { Tundaan } \\
\text { lalu lintas } \\
\text { JiUtamma } \\
\text { (detili) } \\
\text { DMA }\end{array}$ & $\begin{array}{c}\text { Tundaan } \\
\text { lalulintas } \\
\text { JINVinor } \\
\text { (detili) } \\
\text { DNI } \\
\end{array}$ & $\begin{array}{l}\text { Tundaan } \\
\text { geometrilk } \\
\text { simpanng } \\
\text { (detilik) } \\
\text { (DG) }\end{array}$ & $\begin{array}{c}\text { Tundaan } \\
\text { simpang } \\
\text { (detilik) } \\
\text { (D) } \\
\end{array}$ & $\begin{array}{c}\text { Indek } \\
\text { Tinglat } \\
\text { Pelayanan }\end{array}$ & $\begin{array}{l}\text { Arus lalu- } \\
\text { lintas (Q) } \\
\text { smp jam } \\
\text { USIG:I }\end{array}$ & $\begin{array}{c}\text { Capasitas } \\
\text { (C) } \\
\text { smp jam }\end{array}$ & $\begin{array}{c}\text { Derajat } \\
\text { kejenuhan } \\
\text { (DS) } \\
\end{array}$ & $\begin{array}{c}\text { Tundaan } \\
\text { lalulintas } \\
\text { simpang } \\
\text { (detilik) } \\
\text { DII } \\
\end{array}$ & 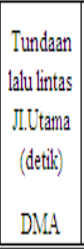 & $\begin{array}{c}\text { Tundaan } \\
\text { lauluintas } \\
\text { J.Minor } \\
\text { (detilik) } \\
\text { DMI } \\
\end{array}$ & $\begin{array}{c}\text { Tundaan } \\
\text { geometrilk } \\
\text { simpang } \\
\text { (detik) } \\
\text { (DG) }\end{array}$ & $\begin{array}{l}\text { Tundaan } \\
\text { simpang } \\
\text { (detili) } \\
\text { (D) }\end{array}$ & $\begin{array}{c}\text { Indel } \\
\text { Tinglat } \\
\text { Pelayanan }\end{array}$ \\
\hline Pada hari & abtu) & & & & & & & & & & & & & & & & & \\
\hline $06.45 \cdot 07.45$ & 2125 & 2,739 & 0.78 & 8.62 & 6.37 & 14.99 & 4.11 & 12.74 & $D$ & 2074 & 3,826 & 0.54 & 5.51 & 4.12 & 9.62 & 4.23 & 9.74 & $c$ \\
\hline $16.00-17.00$ & 2088 & 2,733 & 0.76 & 7.80 & 5.82 & 13.62 & 4.12 & 11.92 & D & 2033 & 3,742 & 0.54 & 5.54 & 4.14 & 9.69 & 4.23 & 9.77 & c \\
\hline Pada hari & linggu) & & & & & & & & & & & & & & & & & \\
\hline $06.45 \cdot 07.45$ & 1232 & 2,672 & 0.46 & 4.71 & 3.52 & 8.22 & 4.27 & 8.98 & $c$ & 1045 & 4,992 & 0.21 & 2.14 & 1.60 & 373 & 4.40 & 6.53 & $B$ \\
\hline $16.45 \cdot 17,45$ & 1083 & 2,671 & 0.41 & 4.14 & 3.09 & 7.23 & 4.30 & 8.43 & $c$ & 948 & 3,533 & 0.27 & 2.74 & 2.04 & 4.78 & 4.37 & 7.10 & $B$ \\
\hline (Pada hari & enin) & & & & & & & & & & & & & & & & & \\
\hline $06.45 \cdot 07.45$ & 2062 & 2,727 & 0.76 & 8.28 & 6.13 & 1.41 & 4.12 & 12.40 & $D$ & 1964 & 3,692 & 0.53 & 5.41 & 4.04 & 9.45 & 4.23 & 9.64 & $c$ \\
\hline $16.15 \cdot 17.15$ & 2140 & 2,721 & 0.79 & 8.03 & 5.99 & 14.02 & 4.11 & 12.13 & $D$ & 2790 & 4,499 & 0.63 & 6.41 & 4.79 & 11.20 & 4.19 & 10.60 & $c$ \\
\hline
\end{tabular}

1. Dengan dilakukan pengaturan lalu lintas pada simpang Jl. Gajah Mada - Jl STKIP PGRIseperti Gambar 3 maka diperoleh pe-ningkatan Kapasitas simpang dari 2.739 smp/jam menjadi 3.826 smp/jam, penurunan Derajat kejenuhan dari 0,78 menjadi 0,54 dan Indek Tingkat Pelayanan (ITP) dari (D) ke (C)hasil lengkap dapat dilihat pada Tabel 10.

2. Pada simpang simpang Jl. Gajah Mada - Jl STKIP PGRI Jl. Dan simpang Jl Gajah Ma-da - Jl Perumahan Tabiang Banda Gadang seperti Gambar 3 terjadi peningkatan Ka-pasitas simpang dari $2.738 \mathrm{smp} / \mathrm{jam}$ menjadi $3.606 \mathrm{smp} / \mathrm{jam}$, penurunan Derajat keje-nuhan dari 0,76 menjadi 0,59 dan Indek Tingkat Pelayanan (ITP) dari (D) ke (C) ha-sil lengkap dapat dilihat pada Tabel 11.

3. Pada ruas jalan antara simpang Jl. Gajah Mada - Jl STKIP PGRI dan Jl. Gajah Mada - Jl Perumahan Tabiang Banda Gadang tidak mengalami perobahan seperti dapat dilihat pada Tabel. 12.

Tabel 11 :Perbandingan Tingkat Pelayanan Simpang Tak Bersinyal Simpang Jl Gajah Mada - Jl Perumahan Tabiang Banda Gadang

\begin{tabular}{|c|c|c|c|c|c|c|c|c|c|c|c|c|c|c|c|c|c|c|}
\hline & & Simpan & g Tiga $\mathrm{B}$ & 3P0MS & $\begin{array}{r}\mathrm{P} \\
\text { Sumbar }\end{array}$ & $\begin{array}{l}\text { erbandil } \\
\text { antara k }\end{array}$ & $\begin{array}{l}\text { ngan Tin } \\
\text { readaan }\end{array}$ & $\begin{array}{l}\text { ingkat } P \\
\text { I sekara }\end{array}$ & $\begin{array}{l}\text { Pelayanal } \\
\text { ang (Exis }\end{array}$ & $\begin{array}{l}\text { n Simpan } \\
\text { ting den }\end{array}$ & $\begin{array}{l}\text { ng Tak } \\
\text { Igan Alt }\end{array}$ & $\begin{array}{l}\text { Bersinyal } \\
\text { ternatif ya }\end{array}$ & $\begin{array}{l}\text { al } \\
\text { rang diust }\end{array}$ & sulkan & pada jam & m sibuk & & \\
\hline & & & & & Existing & & & & & & & & & komend & & & & \\
\hline Jam & 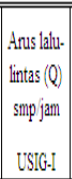 & $\begin{array}{l}\text { Capasitas } \\
\text { (C) } \\
\operatorname{smp} \text { jam }\end{array}$ & \begin{tabular}{|c} 
Derajat \\
kejenuhan \\
(DS)
\end{tabular} & \begin{tabular}{|c|} 
Tundazan \\
|alul-intas \\
simpang \\
(detili) \\
DTI
\end{tabular} & $\begin{array}{l}\text { Tundaan } \\
\text { lalu intas } \\
\text { JiLtama } \\
\text { (detilik) } \\
\text { DMAA }\end{array}$ & 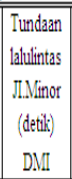 & \begin{tabular}{|l|} 
Tundaan \\
geometrikl \\
simpang \\
(detili) \\
(DG)
\end{tabular} & $\begin{array}{c}\text { Tundazn } \\
\text { simpang } \\
\text { (detili) } \\
\text { (D) }\end{array}$ & $\begin{array}{c}\text { Indel } \\
\text { Tinglat } \\
\text { Pelayanan }\end{array}$ & 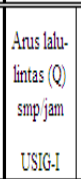 & $\begin{array}{l}\text { Capasitas } \\
\text { (C) } \\
\text { smp jam }\end{array}$ & $\begin{array}{c}\text { Derajat } \\
\text { Regenuman } \\
\text { (DS) }\end{array}$ & \begin{tabular}{|c|} 
Tundaan \\
Ialulintinas \\
simpang \\
(detili) \\
DII \\
\end{tabular} & $\begin{array}{l}\text { Tundaan } \\
\text { lalu intas } \\
\text { JiUtama } \\
\text { (detilik) } \\
\text { DMA } \\
\end{array}$ & \begin{tabular}{|c|} 
Tundazn \\
Ialluintas \\
JIN/inor \\
(detilik) \\
DNI \\
\end{tabular} & $\begin{array}{l}\text { Tundaan } \\
\text { geometrilk } \\
\text { simpang } \\
\text { (detilk) } \\
\text { (DG) }\end{array}$ & $\begin{array}{c}\text { Tundazan } \\
\text { simpang } \\
\text { (detidit) } \\
\text { (D) }\end{array}$ & \begin{tabular}{|c|} 
Indele \\
Tinglat \\
Pelayynann
\end{tabular} \\
\hline Pada hari & i Sabtu) & & & & & & & & & & & & & & & & & \\
\hline $06.45 \cdot 07.15$ & 2074 & 2,738 & 0.76 & 8.30 & 6.14 & 14,4 & 4.12 & 12.42 & $D$ & 2125 & 3,607 & 0.59 & 6.00 & 4.48 & 10.48 & 4.21 & 10.21 & $c$ \\
\hline $16.00 \cdot 17.00$ & 2103 & 2,771 & 0.76 & 8.33 & 6.16 & 14,49 & 4.12 & 12.45 & $D$ & 2158 & 3,742 & 0.58 & 5.87 & 4.38 & 10.25 & 4.21 & 10.08 & $c$ \\
\hline Pada hari & i Minggu) & & & & & & & & & & & & & & & & & \\
\hline $06.45 \cdot 07.45$ & 1295 & 2,764 & 0.47 & 4.78 & 3.57 & 8.35 & 4.27 & 9.05 & $c$ & 1482 & 3,564 & 0.42 & 4.25 & 3.17 & 7.42 & 4.29 & 8.54 & $B$ \\
\hline $16.00 \cdot 17.00$ & 1234 & 2,765 & 0.45 & 4.63 & 3.45 & 8.08 & 4.28 & 8.91 & $c$ & 1375 & 3,582 & 0.38 & 4.13 & 3.07 & 7.20 & 4.31 & 8.4 & $B$ \\
\hline Pada hari & (Senin) & & & & & & & & & & & & & & & & & \\
\hline $06.45 \cdot 07.45$ & 2089 & 2,74 & 0.76 & 8.39 & 6.20 & 14.59 & 4.12 & 12.51 & $D$ & 2188 & 3,582 & 0.61 & 6.25 & 4.66 & 10.91 & 4.19 & 10.4 & $c$ \\
\hline 16.30 - 17,30 & 2059 & 2,767 & 0.74 & 7.59 & 5.67 & 13.27 & 4.13 & 11.72 & c & 2153 & 3,655 & 0.59 & 6.01 & 4.9 & 10.50 & 4.21 & 10.22 & $c$ \\
\hline
\end{tabular}


Tabel 12 :Perbandingan Tingkat Pelayanan Ruas Jalan antara simpang Jl. Gajah Mada - Jl STKIP PGRI dan Jl. Gajah Mada - Jl Perumahan Tabiang Banda Gadang

\begin{tabular}{|c|c|c|c|c|c|c|c|c|}
\hline \multicolumn{9}{|c|}{$\begin{array}{l}\text { Perbandingan Tingkat Pelayanan Ruas Jalan Antara Simpang (Segmen } \\
\text { Simpang Jl. Gajah Mada - Jl. STKIP PGRI sampai Simpang JI Gajah } \\
\text { Mada - Jl. Perumahan Tabiang Banda Gadang) keadaan sekarang (Existing) } \\
\text { dengan Alternatif yang diusulkan (Rekomendasi) pada jam sibuk }\end{array}$} \\
\hline \multirow[b]{2}{*}{ Jam } & \multicolumn{4}{|c|}{ Existing } & \multicolumn{4}{|c|}{ Rekomendasi } \\
\hline & \begin{tabular}{|c|} 
Arus lalu \\
lintas Total \\
$Q$ \\
Smp $/$ Jam \\
\end{tabular} & $\begin{array}{l}\text { Kapasitas } \\
\text { smp/jam }\end{array}$ & $\begin{array}{c}\text { Derajat } \\
\text { Kejenuhan } \\
\text { DS } \\
(\mathrm{Q} / \mathrm{C})\end{array}$ & $\begin{array}{c}\text { Tingkat } \\
\text { Pelayanan }\end{array}$ & $\begin{array}{l}\text { Arus lalu } \\
\text { lintas } \\
\text { Total Q } \\
\text { Smp/Jam }\end{array}$ & $\begin{array}{l}\text { Kapasitas } \\
\text { smp/jam }\end{array}$ & $\begin{array}{c}\text { Derajat } \\
\text { Kejenuhan } \\
\text { DS } \\
(\mathrm{Q} / \mathrm{C})\end{array}$ & $\begin{array}{l}\text { Tingkat } \\
\text { Pelayanan }\end{array}$ \\
\hline \multicolumn{9}{|c|}{ ( hari Sabtu) } \\
\hline $07.00-08.00$ & $2,323.0$ & 2,617 & 0.50 & C & $2,323.0$ & 2,617 & 0.50 & C \\
\hline $16.00-17.00$ & $1,482.1$ & 2,617 & 0.57 & $\mathrm{C}$ & $1,482.1$ & 2,617 & 0.57 & $\mathrm{C}$ \\
\hline \multicolumn{9}{|c|}{ ( hari Minggu ) } \\
\hline $06.45-07.45$ & 818.5 & 2,617 & 0.31 & B & 818.5 & 2,617 & 0.31 & B \\
\hline $16.15-17.15$ & 800.8 & 2,617 & 0.31 & B & 800.8 & 2,617 & 0.31 & B \\
\hline \multicolumn{9}{|c|}{ ( hari Senin) } \\
\hline $06.45-07.45$ & $1,303.3$ & 2,617 & 0.50 & $\mathrm{C}$ & $1,303.3$ & 2,617 & 0.50 & $\mathrm{C}$ \\
\hline $16.15-17.15$ & $1,347.8$ & 2,617 & 0.51 & C & $1,347.8$ & 2,617 & 0.51 & $\mathrm{C}$ \\
\hline
\end{tabular}

Pada Gambar 4 dapat dilihat perobahan Indek Tingkat Pelayanan (ITP) simpang tak bersinyal dan ruas jalan Gajah Mada

\section{KESIMPULAN DAN SARAN}

\subsection{Kesimpulan}

Dari hasil evaluasi didapatkan kapasitas padasimpangJl. Gajah Mada - Jl STKIP PGRIsebesar $2.739 \mathrm{smp} / \mathrm{jam}$ Derajat kejenuhan (DS) $=0,76$, Tundaan simpang $(\mathrm{D})=12,43$ detik dan Indek Tingkat Pelayanan “ D”. Pada simpang Jl Gajah Mada - Jl Perumahan Tabiang Banda Gadang kapasitas sebesar $2.738 \mathrm{smp} / \mathrm{jam}$ Derajat kejenuhan (DS) $=0,76$, Tundaan simpang $(\mathrm{D})=12,42$ detik dan Indek Tingkat Pelayanan “ D”. Sedangkan kapasitas ruas jalan $=2.617 \mathrm{smp} / \mathrm{jam}$, Derajat kejenuhan $(\mathrm{DS})=0,50$ dan Indek Tingkat Pelayanan " $\mathrm{C}$ ". Tingkat pelayanan pejalan kaki pada trotoar dan penyeberang jalan pada simpang Jl. Gajah Mada - Jl STKIP PGRI= A dan fasilitas penyeberang jalan Zebra Cross.

Berdasar hasil analisa diatas untuk meningkatkan kapasitas simpang dilakukan sebagai berikut :

1. Simpang Jl. Gajah Mada - Jl STKIP PGRI dijadikan sebagai arus masuk pa-da kawasan pendidikan dan mengalihkan arus keluar melaluisimpang Jl Gajah Mada - Jl Perumahan Tabiang Banda Gadang.

2. Menutup arus kendaraan yang masuk melalui simpang Jl Gajah Mada - Jl Perumahan Tabiang Banda Gadang-dengan mengalihkan arus masuk melalui simpangJl. Gajah Mada - Jl STKIP PGRI sehingga simpang Jl Gajah Ma-da - Jl Perumahan Tabiang Banda Gadang hanya untuk arus kendaraan yang keluar saja.

3. Pada simpangJl Gajah Mada - Jl STKIP PGRI dan Simpang Jl Gajah Mada - Jl Perumahan Tabiang Banda Gadangterdapat 9 titik konflik lalu lintas.

Dengan dilakukannya pengaturan arus ken-daraan keluar masuk melalui simpang Jl Ga-jah Mada Jl STKIP PGRI dan simpang Jl Gajah Mada - Jl Perumahan Tabiang Banda Gadang didapatkan hasil sebagai berikut :

1. Padasimpang J1 Gajah Mada - Jl STKIP PGRI,terjadi peningkatan kapasitas simpang $40 \%$, mengurangi Tundaan simpang \pm 2 - 3 detik sertameningkatkan Indek Tingkat Pelayanan dari "D" menjadi "C" 
2. Pada simpang Jl Gajah Mada - Jl Pe-rumahan Tabiang Banda Gadang terjadi peningkatan Kapasitas simpang $32 \%$, mengurangi Tundaan simpang \pm 2 - 3 detik dan meningkatkan Indek Tingkat Pelayanan dari "D" menjadi "C".

3. Mengurangi titik konflik lalu lintas dari 9 menjadi 6 titik konflik pada simpangJl Gajah Mada - J1 STKIP PGRI dan Simpang Jl Gajah Mada - J1 Peruma-han Tabiang Banda Gadang.

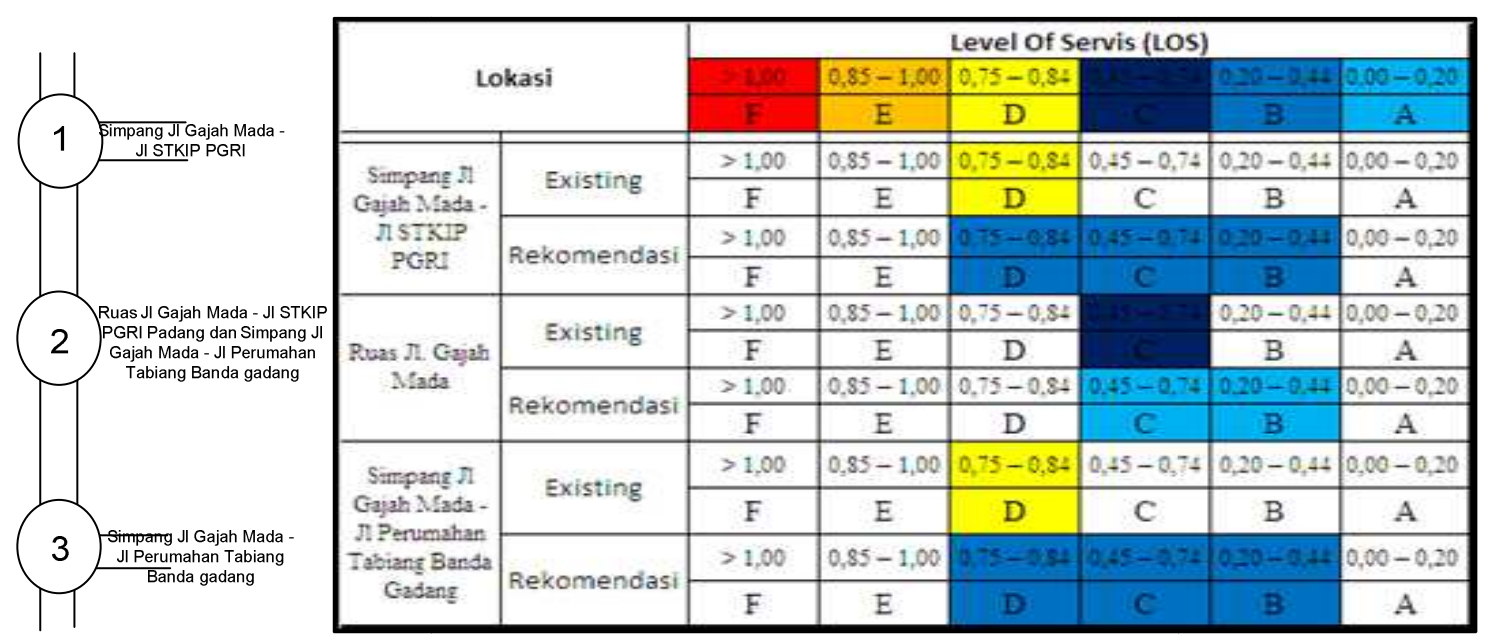

Gambar 4..Perbandingan Indek Tingkat Pelayanan pada Simpang tak bersinyal dan Ruas Jalan Gajah Mada

\subsection{Saran}

Perlu dilakukan penelitian lebih lanjut pada area kawasan pendidikan, perkantoran dan pemukiman guna membandingkan antara kondisi eksisting dan setelah diterapkan manajemen lalu lintas dengan beberapa faktor yang mempengaruhi pengguna jalan/pengendara kendaraan seperti waktu tempuh, jarak tempuh dan biaya bahan bakar dengan melakukan quesiner terhadap pengendara kendaraan.

\section{DAFTAR KEPUSTAKAAN}

Brisbane City Council encourages coordi-nated transport"http://www.Brisbane. qld.gov.au/downloads/traffic_transport/LATM_factsheet.pdf” diakses tanggal 15 Mei 2009

Badan Perencanaan Pembangunan Daerah Kota Padang 2010 Rencana Tata Ruang Wilayah (RTRW) Kota Padang Tahun 2008-2028 “.

Direktur Jenderal Bina Marga 1995Tata CaraPerencanaan Fasilitas Pejalan Kaki di Kawasan Perkotaan (Nomor 011/T/Bt/1995) Jalan, Jakarta.

Direktur Jenderal Bina Marga, 1997, .Manual Kapsitas Jalan Indonesia (MKJI), Departemen Pekerjaan Umum, Sweroad \& PT Bina Karya (Persero) Jakarta.

Direktur Jenderal Bina Marga Tahun 1999 Pedoman Perencanaan Jalur Pejalan Kaki Pada Jalan Umum Penerbit PT. Mediatama Saptakarya (PT. Medisa)

Dinas Perhubungan DKIJakarta, 2009“ Pembenahan Transportasi Jakarta/Penerapan Local Area Traffic Management " http://id.wikibooks.Org/wiki/PembenahanTransportasiJakarta / PenerapanLocalAreaTraffic Managementdiakses tanggal 05 Mei 2009

Dinas Perhubungan Kota Padang, 2010 Rencana Induk Transportasi Kota Padang”

Falkenberg, M 2009,Local Area Traffic Management - a Victorian approach http://www.ite.org/traffic/.../AB05H5004.pdf. diakses tanggal 15 mei 2009

Morlok, E. K., 1991 .Pengantar Teknik dan Perencanaan Transporta-si..terjemahan Ir. Johan Kelanaputra Harmin, PenerbitErlangga, Jakarta.

Munawar, A. 2006, "Manajemen Lalu Lintas Perkotaan" Cetakan ke 2,Betta offset, Yogyakarta.

Nasution, (2003), “Metodologi Penelitian Naturalistik - Kuantitatif” Penerbit Transito, Bandung . 
Pemerintah Republik Indonesia “Peraturan Pemerintah Nomor 43 /1993" Tentang Prasarana Dan Lalu Lintas Jalan.

Peraturan Menteri Perhubungan Republik Indonesia Nomor 14/2006, tentang Manajemen dan Rekayasa Lalu Lintas di Jalan.

Pemerintah Republik Indonesia "Undang-Undang Nomor 22/2009” Tentang Lalu Lintas Dan Angkutan Jalan,

Robertson P, (2009) "Local Area Traffic Management Study" http://www.albany.wa.gov.au/download/2476 diakses tanggal 13 Mei 2009

Sinulingga, B.D, 1999,. Pembangunan Kota Tinjauan Regional dan Lokal, Penerbit Pustaka Sinar Harapan,

Smith, B\& Simons, P, 2009 “ Bowden, Brompton, Ridleyton \& Ovingham Local Area Traffic Management Plan "http: // www. charlessturt.sa.gov.au /webdata /resources/files/Bowden_and_Brompton, diakses tanggal 15 Mei 2009

Tamin, O.Z., 2000, .Perencanaan dan Pemodelan Transportasi.. ed.ke-2, Bandung .

Tamin O.Z.,\&Nahdalina., 1998 .Analisa dampak lalu lintas (Andall).. journal perencanaan wilayah dan kota, Bandung .

Transportation Research Board, Highway Capacity Manual, (1985), Washington DC., National Research Council, 